\title{
Seed protein, oil, fatty acids, and minerals concentration as affected by foliar K-glyphosate applications in soybean cultivars ${ }^{*}$
}

\author{
Manju Pande ${ }^{1 \#}$, Mudlagiri B. Goli ${ }^{1}$, Tyneiseca Epps ${ }^{1}$, Nacer Bellaloui ${ }^{2}$ \\ ${ }^{1}$ Department of Natural Sciences and Environmental Health, Mississippi Valley State University, Itta Bena, USA; \\ ${ }^{\#}$ Corresponding Author: mpande@mvsu.edu \\ ${ }^{2}$ Crop Genetics Research Unit, USDA-ARS, Stoneville, USA
}

Received 4 July 2012; revised 22 August 2012; accepted 10 September 2012

\begin{abstract}
Previous studies showed that glyphosate (Gly) may chelate cation nutrients, including potassium (K), which might affect the nutritional status of soybean seed. The objective of this study was to evaluate seed composition (protein, oil, fatty acids, and minerals) as influenced by foliar applications of K + Gly. A greenhouse experiment was conducted at Mississippi Valley State University, using two glyphosate-resistant soybean cultivars DK 4968 and Pioneer 95Y70 grown in a randomized complete block design. The treatments were foliar applications of $K$ alone, Gly alone, K + Gly combined, and nontreated control (C). A single application of potassium $\left(1.75 \%\right.$ as $\left.\mathrm{K}_{2} \mathrm{SO}_{4}\right)$ was applied, and Gly was applied at a rate of 0.75 ae/ha at V5 stage. Leaf samples were harvested one week after treatment (1WAT) and 3WAT. Mature seeds were collected at harvest maturity (R8). The results showed that $K$, nitrogen (N), and phosphorus (P) concentrations increased in leaves in $K$ alone and K + Gly treatments at 1WAT, but significantly increased at 3WAT in all treatments. The concentration of iron ( $\mathrm{Fe}$ ) and zinc ( $\mathrm{Zn})$ showed a decrease in leaf concentration in Gly and K + Gly treatments compared to $C$. Boron (B) concentration increased in Gly treatment. Seed protein percentage was higher in all treatments in cultivar DK 4968, and the increase was about $4.0 \%$ in $\mathrm{K}$ treatment, $6.9 \%$ in Gly treatment, and 3.5\% in $\mathrm{K}+$ Gly treatment compared to $\mathrm{C}$. The opposite trend was observed in oil concentration, especially in Gly treatment where the percentage
\end{abstract}

\footnotetext{
"Mention of trade names or commercial products in this publication is solely for the purpose of providing specific information and does not imply recommendation or endorsement by the US Department of Agriculture.
}

decrease was $11.2 \%$ compared to C. Stearic fatty acid was significantly higher in $\mathrm{K}+$ Gly treatment compared to $K$ treatment for DK 4968 . A higher percentage increase in linolenic acid was observed in DK 4968 in $K$ treatment (an increase of $24.5 \%$ ) and in $\mathrm{K}+$ Gly treatment (an increase of 29.5\%) compared to C. In Pioneer 95Y70, the decrease in oil was $2.7 \%$ in $\mathrm{K}$ treatment and $2.3 \%$ in $\mathrm{K}+$ Gly treatment compared to C. Stearic acid in Pioneer 95Y70 was significantly higher in Gly treatment, an increase of $8.3 \%$, compared to C. Our research demonstrated that foliar application of K and Gly altered mineral concentration in leaves and shifted seed composition towards protein and stearic concentration. Further research under field conditions is needed before final conclusions are made.

Keywords: Fatty Acids; Glyphosate; Nutrition; Oil; Potassium; Protein; Seed Composition; Soybean

\section{INTRODUCTION}

Soybean is a source of protein, desirable amino acids, and fatty acids. Recent research showed that soy protein contains balanced amino acids and phytoestrogen such as isoflavones, which have positive health benefits [1]. Soy products have also been used to prevent and treat bone resorption, inhibiting ovarian and colon cancer and other chronic diseases [2-6]. Compared with casein, dietary soy has been found to slow the progression of chronic renal injury in animals [7]).

Potassium $(\mathrm{K})$ is one of the three major essential nutrients required by plants. Plants need large quantities of potassium, and $\mathrm{K}$ is removed by most crops more than any other nutrients, indicating the need to apply an adequate amount of $\mathrm{K}$ fertilizer [8]. Since $\mathrm{K}$ is involved in enzyme activation, sugar transport, chlorophyll produc- 
tion, and in regulating water balance, $\mathrm{K}$ deficiency can severely impair protein synthesis resulting in accumulation of free amino acid concentration in soybean plant tissue [9], affecting plant growth, yield, and increased susceptibility to pests. Potassium is transferred from vegetative parts to seed during pod- and seed-fill. The mature soybean seed contains nearly $60 \%$ of the total $\mathrm{K}$ in a plant [10-12], any deficiency of $\mathrm{K}$ during rapid vegetative growth until seed fill stages will affect soybean yield and seed quality. Earlier studies have reported that $\mathrm{K}$ deficiency in soybean resulted in reduction in yield, seed oil, and K concentrations in seed [13]. Recent research confirms the importance of maintaining high concentration of $\mathrm{K}$ in plant tissue and seed, and higher seed $\mathrm{K}$ is positively associated with yield and quality $[1,14]$. Glyphosate (Gly) herbicide application has been efficient for weed control, but its possible binding to cation nutrients such $\mathrm{K}$ is still a concern. Since previous results showed that there were no conclusive effects of glyphosate on $\mathrm{K}$ concentration in leaves and seeds in glyphosate-resistant soybean, the objective of this research was to examine the effect of foliar application of combined $\mathrm{K}$ and Gly on mineral concentrations in leaves and seed protein, oil, and fatty acids in two soybean cultivars.

\section{MATERIALS AND METHODS}

\subsection{Treatment and Experiment Design}

A greenhouse experiment was conducted at Mississippi Valley State University (Itta Bena, MS). Glyphosate-resistant soybean cultivars DK 4968 and Pioneer 95 Y70 were planted in 96 pots, arranged in a randomized complete block design. Four replicates were used. Soil moisture was monitored using soil water potential sensors (densitometers), and plants were grown under natural light during the normal growing season (from April to September) for the Early Soybean Production System in the misdoubt USA. Temperature during the soybean growing season ranged from $21^{\circ} \mathrm{C}$ to $40^{\circ} \mathrm{C}$. The plants were watered as needed. Treatments were applied six weeks after planting (V4-V5 stage). The treatments were: control (non-treated), foliar potassium treatment alone $(\mathrm{K})$ $\left(1.75 \%\right.$ as $\left.\mathrm{K}_{2} \mathrm{SO}_{4}\right)$, glyphosate (Gly) application alone at a rate of $0.75 \mathrm{ae} / \mathrm{ha}$, and $\mathrm{K}+$ Gly combined $(1.75 \%$ as $\mathrm{K}_{2} \mathrm{SO}_{4}+$ Gly at rate of $0.75 \mathrm{ae} / \mathrm{ha}$ ).

\subsection{Harvesting}

Soybean leaves, stems, and root were collected from each treatment one week after the treatment (1WAT) and $3 \mathrm{WAT}$. At 12WAT (harvest maturity, R8), mature seeds were collected for seed protein, oil, and fatty acid analysis.

\subsection{Leaf and Seed Analysis}

Leaf and seed samples were collected from each treatment. Five grams of dry, ground leaf samples were analyzed by Soil, Plant, and Water laboratory, Athens, GA. Twenty five grams of whole seed samples were analyzed for protein, oil, and fatty acids using Near Infra Red (NIR) reflectance [15] at USDA-ARS Delta States Research Center in Stoneville, MS. Statistical analyses were performed using ANOVA in SAS. Level of significance was at $\mathrm{P} \leq 0.05$.

\section{RESULTS}

\subsection{Leaf Mineral Concentration}

Foliar application of $\mathrm{K}$ and $\mathrm{K}+$ Gly at both 1WAT and $3 \mathrm{WAT}$ resulted in higher leaf $\mathrm{K}$ concentration in cultivar DK 4968 (Tables 1 and 2). Nitrogen concentration increased in Gly treatment at 1WAT, whereas $\mathrm{N}$ concentration increased in all treatments at 3WAT (Tables 1 and 2). Phosphorus increased in Gly and K + Gly treatments at 1WAT and increased in all treatments at 3 WAT. Sulfur increased in K and Gly at $1 \mathrm{WAT}$ and 3WAT (Tables 1 and 2). The concentration of Fe decreased in all treatments at 1WAT and decreased in Gly and $\mathrm{K}+$ Gly at $3 \mathrm{WAT}$. Zinc concentration increased

Table 1. Mean values of leaf mineral concentration after 1 week after treatment (1WAT) in DK 4968 and Pioneer $95 \mathrm{Y} 70$ as affected by K, glyphosate (Gly), and K + Gly applications.

\begin{tabular}{|c|c|c|c|c|c|c|c|c|c|c|c|c|c|c|c|}
\hline \multicolumn{8}{|c|}{ DK 4968} & \multicolumn{8}{|c|}{ Pioneer $95 Y 70$} \\
\hline Treatment & $\mathrm{K}(\%)$ & N (\%) & $\mathrm{P}(\%)$ & $\mathrm{S}(\%)$ & $\begin{array}{c}\mathrm{B} \\
(\mathrm{mg} / \mathrm{kg})\end{array}$ & $\begin{array}{c}\mathrm{Fe} \\
(\mathrm{mg} / \mathrm{kg})\end{array}$ & $\underset{(\mathrm{mg} / \mathrm{kg})}{\mathrm{Zn}}$ & Treatment & $\mathrm{K}(\%)$ & N (\%) & $\mathrm{P}(\%)$ & $\mathrm{S}(\%)$ & $\begin{array}{c}\mathrm{B} \\
(\mathrm{mg} / \mathrm{kg})\end{array}$ & $\begin{array}{c}\mathrm{Fe} \\
(\mathrm{mg} / \mathrm{kg})\end{array}$ & $\begin{array}{c}\mathrm{Zn} \\
(\mathrm{mg} / \mathrm{kg})\end{array}$ \\
\hline $\mathrm{C}$ & $2.7 \mathrm{~b}$ & $4.1 \mathrm{cb}$ & $0.47 \mathrm{c}$ & $0.45 b$ & $58.6 \mathrm{~b}$ & $235 \mathrm{a}$ & $64.2 \mathrm{~b}$ & $\mathrm{C}$ & $2.9 \mathrm{~b}$ & $4.2 \mathrm{c}$ & $0.49 \mathrm{c}$ & $0.44 \mathrm{c}$ & $63.4 \mathrm{bc}$ & $140 \mathrm{a}$ & $72.8 \mathrm{a}$ \\
\hline $\mathrm{K}$ & $3.0 \mathrm{a}$ & $4.3 b$ & $0.47 \mathrm{c}$ & $0.53 \mathrm{a}$ & $58.9 \mathrm{~b}$ & $101 b$ & $61.3 \mathrm{~b}$ & K & $2.9 \mathrm{~b}$ & $4.6 \mathrm{~b}$ & $0.55 b$ & $0.54 b$ & $62.2 \mathrm{c}$ & $106 c$ & $69.3 \mathrm{ab}$ \\
\hline Gly & $2.8 \mathrm{~b}$ & $5.0 \mathrm{a}$ & $0.58 \mathrm{a}$ & $0.57 \mathrm{a}$ & $65.6 \mathrm{a}$ & $100 \mathrm{~b}$ & $62.6 \mathrm{~b}$ & Gly & $2.9 \mathrm{~b}$ & $4.8 \mathrm{ab}$ & $0.60 \mathrm{ab}$ & $0.54 \mathrm{~b}$ & $68.5 \mathrm{a}$ & $123 b$ & $66.6 \mathrm{~b}$ \\
\hline K + Gly & $2.9 \mathrm{a}$ & $3.8 \mathrm{c}$ & $0.59 \mathrm{a}$ & $0.35 \mathrm{c}$ & $65.7 \mathrm{a}$ & $116 \mathrm{~b}$ & $72.0 \mathrm{a}$ & $\mathrm{K}+$ Gly & $3.1 \mathrm{a}$ & $4.8 \mathrm{a}$ & $0.63 a$ & $0.60 \mathrm{a}$ & $64.2 \mathrm{~b}$ & $123 b$ & $69.0 \mathrm{ab}$ \\
\hline
\end{tabular}

Note: Means within a column between treatments, followed by the same letter are not significantly different at $\mathrm{P} \leq 5 \%$. 
Table 2. Mean values of leaf mineral concentration after 3 weeks after treatment (3WAT) in DK 4968 and Pioneer 95 Y70 as affected by K, glyphosate (Gly), and K + Gly applications.

\begin{tabular}{|c|c|c|c|c|c|c|c|c|c|c|c|c|c|c|c|}
\hline \multicolumn{8}{|c|}{ DK 4968} & \multicolumn{8}{|c|}{ Pioneer $95 \mathrm{Y} 70$} \\
\hline Treatment & $\mathrm{K}(\%)$ & $\mathrm{N}(\%)$ & $\mathrm{P}(\%)$ & $\mathrm{S}(\%)$ & $\begin{array}{c}\mathrm{B} \\
(\mathrm{mg} / \mathrm{kg})\end{array}$ & $\begin{array}{c}\mathrm{Fe} \\
(\mathrm{mg} / \mathrm{kg})\end{array}$ & $\begin{array}{c}\mathrm{Zn} \\
(\mathrm{mg} / \mathrm{kg})\end{array}$ & Treatment & $\mathrm{K}(\%)$ & $\mathrm{N}(\%)$ & $\mathrm{P}(\%)$ & S (\%) & $\begin{array}{c}\mathrm{B} \\
(\mathrm{mg} / \mathrm{kg})\end{array}$ & $\begin{array}{c}\mathrm{Fe} \\
(\mathrm{mg} / \mathrm{kg})\end{array}$ & $\begin{array}{c}\mathrm{Zn} \\
(\mathrm{mg} / \mathrm{kg})\end{array}$ \\
\hline $\mathrm{C}$ & $2.3 \mathrm{c}$ & $2.7 \mathrm{c}$ & $0.35 \mathrm{c}$ & $0.23 \mathrm{c}$ & $56.4 \mathrm{c}$ & $77.6 \mathrm{a}$ & $135 b$ & $\mathrm{C}$ & $2.6 \mathrm{c}$ & $2.9 \mathrm{c}$ & $0.31 \mathrm{c}$ & $0.23 \mathrm{a}$ & $62.8 \mathrm{~b}$ & $177 \mathrm{a}$ & $73.8 \mathrm{a}$ \\
\hline K & $2.7 b$ & $3.5 \mathrm{ab}$ & $0.40 \mathrm{~b}$ & $0.28 \mathrm{~b}$ & $67.9 \mathrm{a}$ & $74.0 \mathrm{ab}$ & $160 \mathrm{a}$ & K & $2.7 b$ & $3.3 \mathrm{a}$ & $0.38 \mathrm{~b}$ & $0.23 \mathrm{a}$ & $65.0 \mathrm{ab}$ & $155 \mathrm{~b}$ & $74.8 \mathrm{a}$ \\
\hline Gly & $2.9 \mathrm{a}$ & $3.7 \mathrm{a}$ & $0.45 \mathrm{a}$ & $0.36 \mathrm{a}$ & $63.2 \mathrm{~b}$ & $57.9 \mathrm{c}$ & $151 \mathrm{ab}$ & Gly & $3.0 \mathrm{a}$ & $3.1 \mathrm{~b}$ & $0.42 \mathrm{a}$ & $0.24 \mathrm{a}$ & $66.0 \mathrm{a}$ & $139 \mathrm{c}$ & $56.1 \mathrm{c}$ \\
\hline $\mathrm{K}+\mathrm{Gly}$ & $2.87 \mathrm{a}$ & $3.5 \mathrm{~b}$ & $0.45 \mathrm{a}$ & $0.23 \mathrm{c}$ & $63.3 \mathrm{~b}$ & $66.3 b c$ & $152 \mathrm{ab}$ & $\mathrm{K}+$ Gly & $2.8 \mathrm{~b}$ & $3.3 \mathrm{a}$ & $0.43 \mathrm{a}$ & $0.26 \mathrm{a}$ & $62.3 \mathrm{~b}$ & $140 \mathrm{c}$ & $66.0 \mathrm{~b}$ \\
\hline
\end{tabular}

Note: Means within a column between treatments, followed by the same letter are not significantly different at $\mathrm{P} \leq 5 \%$.

in $\mathrm{K}+$ Gly at $1 \mathrm{WAT}$, while increased in $\mathrm{K}$ at $3 \mathrm{WAT}$ (Tables 1 and 2). Concentration of B increased in Gly and $\mathrm{K}+$ Gly treatment at $1 \mathrm{WAT}$ and in all treatments at 3WAT (Tables 1 and 2).

In cultivar Pioneer 95Y70, foliar application of $\mathrm{K}+$ Gly treatment at 1WAT and 3WAT resulted in higher leaf $\mathrm{K}$ concentration in all three treatments. Concentrations of $\mathrm{N}$ and $\mathrm{P}$ increased in all treatments at 1WAT and 3WAT. Sulfur concentration increased in all treatments at $1 \mathrm{WAT}$, while no changes were found at $3 \mathrm{WAT}$. Iron concentration decreased in all treatments at 1WAT and 3WAT. Zinc concentration decreased in Gly treatment at 1WAT and decreased in Gly and K + Gly treatments at 3WAT, contrasting to what was recorded in DK 4968. Significant increase in B concentration was observed in Gly treatment at 1WAT and 3WAT.

\subsection{Seed Mineral Concentration}

The mineral concentration in seed of DK 4968 followed similar trend as those in leaf minerals (Table 3). Concentrations of $\mathrm{P}$ increased in Gly and $\mathrm{K}+$ Gly treatments, $\mathrm{K}$ increased in $\mathrm{K}+$ Gly treatment. However, no significant changes were observed in seed $\mathrm{N}$ concentration. Seed $\mathrm{S}$ concentration decreased in all treatments unlike leaf concentrations. The concentration of Fe decreased in seeds following similar pattern as in the leaves. Zinc concentration in seeds also decreased, whereas B concentration increased only in $\mathrm{K}$ treatment. In Pioneer 95Y70, $\mathrm{K}$ and $\mathrm{P}$ concentrations increased in Gly and $\mathrm{K}+$ Gly treatments, whereas $\mathrm{N}$ decreased in all treatments in seeds. Sulfur concentration decreased in seed in Gly and $\mathrm{K}+$ Gly combined treatment. Iron concentration decreased in $\mathrm{K}$ and Gly, whereas $\mathrm{Zn}$ and $\mathrm{B}$ increased in all treatments.

\subsection{Seed Protein, Oil, and Fatty Acid}

In DK 4968, protein percentage was higher in all treatments compared to the control (Table 4). The percentage increase was $3.9 \%$ in $\mathrm{K}$ treatment, $6.9 \%$ in Gly treatment, and $3.5 \%$ in $\mathrm{K}+$ Gly combined treatments. Oil percentage decreased in Gly and $\mathrm{K}+$ Gly treatments, and the lowest percentage decrease of $11.2 \%$ was recorded in Gly treatment, and the highest protein percentage increase was also observed in the same treatment. Palmitic and stearic acid percentages decreased in $\mathrm{K}$ treatment, while no significant changes were found in Gly or $\mathrm{K}+$ Gly (Table 4). A percentage increase of $6.5 \%$ in unsaturated fatty acids oleic and $2.1 \%$ in linolenic was observed in Gly treatment, The $\mathrm{K}$ treatment resulted in a decrease of oleic acid by $8.8 \%$ and linolenic acid by $24.5 \%$, while in $\mathrm{K}+$ Gly combined treatment no significant change was observed in oleic acid. However, the combined treatment resulted in an increase in linolenic acid by $29.5 \%$, while decreasing linoleic acid by $0.9 \%$ in Gly and $2.34 \%$ decrease in $\mathrm{K}+$ Gly respectively (Table 4).

In Pioneer 95Y70, however, protein percentage decreased by $4.7 \%$ with Gly treatment, whereas, no significant changes were observed in $\mathrm{K}$ or $\mathrm{K}+$ Gly treatments (Table 5). The decrease in oil was $2.7 \%$ in $\mathrm{K}$ and $2.3 \%$ in $\mathrm{K}+$ Gly treatments compared to control. Palmitic acid increased by $14.2 \%$ in $\mathrm{K}$ and by $9.8 \%$ in $\mathrm{K}$ + Gly treatments. Stearic acid increased by $6.9 \%$ in K and by $8.3 \%$ in Gly treatments, while oleic acid decreased by $12.5 \%$ in $\mathrm{K}$ treatment and $12.7 \%$ in $\mathrm{K}+$ Gly treatment. Linoleic and linolenic acids were relatively stable in all treatments, except in Gly treatment where linolenic acid decreased by $11.2 \%$ compared to control.

\section{DISCUSSION}

\subsection{Leaf and Seed Minerals}

The higher concentrations of K, N, P, and B in leaves and seeds as a result of $\mathrm{K}$ and Gly applications indicated that $\mathrm{K}$ and glyphosate enhanced the accumulation of these nutrients in leaves and seeds. The mechanisms of how Gly affects nutrients uptake is not fully understood. Previous research showed that $\mathrm{K}$ application enhanced uptake of macro- and micronutrients in soybean under 
Table 3. Mean values of seed mineral concentrations in DK 4968 and Pioneer 95 Y70 as affected by K, glyphosate (Gly), and K + Gly applications.

\begin{tabular}{|c|c|c|c|c|c|c|c|}
\hline \multicolumn{8}{|c|}{ DK 4968} \\
\hline Treatment & $\mathrm{K}(\%)$ & $\mathrm{N}(\%)$ & $\mathrm{P}(\%)$ & S (\%) & $\mathrm{B}(\mathrm{mg} / \mathrm{kg})$ & $\mathrm{Fe}(\mathrm{mg} / \mathrm{kg})$ & $\mathrm{Zn}(\mathrm{mg} / \mathrm{kg})$ \\
\hline $\mathrm{C}$ & $1.84 \mathrm{~b}$ & $5.90 \mathrm{a}$ & $0.48 \mathrm{~b}$ & $0.33 b$ & $26.44 \mathrm{~b}$ & $71.2 \mathrm{a}$ & $50.8 \mathrm{a}$ \\
\hline $\mathrm{K}$ & $1.84 \mathrm{~b}$ & $5.85 \mathrm{a}$ & $0.49 \mathrm{~b}$ & $0.26 \mathrm{c}$ & $30.62 \mathrm{a}$ & $62.6 \mathrm{~b}$ & $41.3 b$ \\
\hline Gly & $1.80 \mathrm{c}$ & $5.88 \mathrm{a}$ & $0.52 \mathrm{a}$ & $0.35 \mathrm{a}$ & $27.68 \mathrm{~b}$ & $68.2 \mathrm{ab}$ & $43.6 \mathrm{~b}$ \\
\hline $\mathrm{K}+$ Gly & $1.89 \mathrm{a}$ & $5.85 \mathrm{a}$ & $0.52 \mathrm{a}$ & $0.242 \mathrm{c}$ & $27.40 \mathrm{~b}$ & $65.0 \mathrm{~b}$ & $40.6 \mathrm{~b}$ \\
\hline \multicolumn{8}{|c|}{ Pioneer $95 Y 70$} \\
\hline Treatment & $\mathrm{K}(\%)$ & $\mathrm{N}(\%)$ & $\mathrm{P}(\%)$ & $\mathrm{S}(\%)$ & $\mathrm{B}(\mathrm{mg} / \mathrm{kg})$ & $\mathrm{Fe}(\mathrm{mg} / \mathrm{kg})$ & $\mathrm{Zn}(\mathrm{mg} / \mathrm{kg})$ \\
\hline $\mathrm{C}$ & $1.81 \mathrm{~b}$ & $5.94 \mathrm{a}$ & $0.48 \mathrm{~b}$ & $0.31 \mathrm{a}$ & $32.8 \mathrm{c}$ & $114 \mathrm{a}$ & $48.7 b$ \\
\hline $\mathrm{K}$ & $1.87 \mathrm{~b}$ & $5.79 \mathrm{~b}$ & $0.5 b$ & $0.29 \mathrm{a}$ & $35.5 \mathrm{~b}$ & $84 \mathrm{~b}$ & $53.33 \mathrm{a}$ \\
\hline Gly & $1.90 \mathrm{a}$ & $5.77 \mathrm{~b}$ & $0.56 \mathrm{a}$ & $0.25 \mathrm{~b}$ & $35.7 b$ & $84 \mathrm{~b}$ & $53.2 \mathrm{a}$ \\
\hline K + Gly & $189 a$ & $5.72 \mathrm{~b}$ & $0.56 \mathrm{a}$ & $0.25 b$ & $37.8 \mathrm{a}$ & $99 \mathrm{ab}$ & $55.5 \mathrm{a}$ \\
\hline
\end{tabular}

Note: Means within column in the treatments, followed by the same letter are not significantly different at $\mathrm{P} \leq 5 \%$.

Table 4. Mean values of protein, oil, and fatty acid percentages (\%) in soybean seeds in cultivar DK 4968 as affected by K, glyphosate (Gly), and K + Gly applications.

\begin{tabular}{|c|c|c|c|c|c|c|c|}
\hline Treatment & Protein & Oil & Palmitic & Stearic & Oleic & Linoleic & Linolenic \\
\hline $\mathrm{C}$ & $37.97 \mathrm{c}$ & $22.63 \mathrm{a}$ & $10.8 \mathrm{a}$ & $4.03 \mathrm{a}$ & $20.83 b$ & $59.13 \mathrm{a}$ & $6.47 \mathrm{c}$ \\
\hline \multirow{2}{*}{$\mathrm{K}$} & $39.48 b$ & $21.9 \mathrm{ab}$ & $9.98 \mathrm{~b}$ & $3.68 \mathrm{~b}$ & $19 \mathrm{c}$ & $59.43 \mathrm{a}$ & $8.05 \mathrm{ab}$ \\
\hline & $(+3.9)$ & $(-3.2)$ & $(-7.6)$ & $(-8.8)$ & $(-8.8)$ & $(+0.5)$ & $(-24.5)$ \\
\hline \multirow{2}{*}{ Gly } & $40.6 \mathrm{a}$ & $20.1 \mathrm{c}$ & $10.9 \mathrm{a}$ & $4 \mathrm{a}$ & $22.2 \mathrm{a}$ & $58.6 \mathrm{~b}$ & $6.6 \mathrm{~b}$ \\
\hline & $(+6.9)$ & $(-11.2)$ & $(-0.1)$ & $(-0.83)$ & $(+6.5)$ & $(-0.9)$ & $(+2.1)$ \\
\hline \multirow{2}{*}{$\mathrm{K}+\mathrm{Gly}$} & $39.3 b$ & $21.7 \mathrm{bc}$ & $11 \mathrm{a}$ & $4.08 \mathrm{a}$ & $20.3 b$ & $57.75 b$ & $8.38 \mathrm{a}$ \\
\hline & $(+3.5)$ & $(-4.1)$ & $(+1.8)$ & $(+1.03)$ & $(-2.56)$ & $(-2.34)$ & $(+29.5)$ \\
\hline
\end{tabular}

Notes: Values within a column between treatments, followed by the same letter are not significantly different at $\mathrm{P} \leq 5 \%$. Values in parenthesis indicate percentage increase $(+)$ and decrease $(-)$ compared to control.

Table 5. Mean values of protein, oil, and fatty acid percentages (\%) in soybean seeds in cultivar Pioneer $95 \mathrm{Y} 70$ as affected by K, glyphosate (Gly), and K + Gly applications.

\begin{tabular}{|c|c|c|c|c|c|c|c|}
\hline Treatment & Protein & Oil & Palmitic & Stearic & Oleic & Linoleic & Linolenic \\
\hline $\mathrm{C}$ & $39.25 \mathrm{ab}$ & $22.82 \mathrm{a}$ & $10.2 \mathrm{c}$ & $3.6 \mathrm{~b}$ & $20.17 \mathrm{a}$ & $59.95 \mathrm{ab}$ & $7.35 \mathrm{a}$ \\
\hline \multirow{2}{*}{ K } & $39.5 \mathrm{a}$ & $22.2 b$ & $11.65 \mathrm{a}$ & $3.85 \mathrm{a}$ & $17.65 \mathrm{~b}$ & $60.5 a$ & 7.05ab \\
\hline & $(+0.64)$ & $(-2.7)$ & $(+14.2)$ & $(+6.9)$ & $(-12.5)$ & $(+0.9)$ & $(-4.0)$ \\
\hline \multirow{2}{*}{ Gly } & $37.37 \mathrm{c}$ & $22.95 \mathrm{a}$ & $10.67 \mathrm{bc}$ & $3.9 \mathrm{a}$ & $19.75 \mathrm{a}$ & $59.3 \mathrm{~b}$ & $6.52 b$ \\
\hline & $(-4.7)$ & $(+0.57)$ & $(+4.6)$ & $(+8.3)$ & $(-2.08)$ & $(-1.08)$ & $(-11.2)$ \\
\hline \multirow{2}{*}{ K + Gly } & $38.47 \mathrm{~b}$ & $22.3 \mathrm{~b}$ & $11.2 \mathrm{ab}$ & $3.67 \mathrm{~b}$ & $17.6 \mathrm{~b}$ & $59.72 \mathrm{~b}$ & $7.4 \mathrm{a}$ \\
\hline & $(-1.9)$ & $(-2.3)$ & $(+9.8)$ & $(+2.3)$ & $(-12.7)$ & $(-0.38)$ & $(+0.68)$ \\
\hline
\end{tabular}

Notes: Values within a column between treatments, followed by the same letter are not significantly different at $\mathrm{P} \leq 5 \%$. Values in parenthesis indicate percentage increase $(+)$ /decrease $(-)$ compared to control. 
soybean-wheat-maize rotation conditions [12]. The increase of $\mathrm{N}$ in leaves and seed could be due to the close relationship between $\mathrm{K}$ and nitrogen assimilation, especially nitrate reductase activity, the limiting step in nitrogen assimilation. Potassium application resulted in increased chlorophyll content, nitrate reductase activity in soybean, whereas the application of Gly at $0.84,1.68$, $2.52+2.52$, and $0.84+0.84 \mathrm{~kg}$ ae/ha reduced foliar nitrogen by $26 \%-42 \%$ [16]. Reports on $\mathrm{N}$ acquisition and mobilization from vegetative tissue to seed, which determine seed protein, are still conflicting [17], although the role of $\mathrm{K}, \mathrm{B}$ and $\mathrm{Zn}$ in protein synthesis have been well established [18]. For example, it was found that $\mathrm{K}$ application at anthesis to K-deprived plants enhanced the photosynthetic capacity, leading to alteration in seed protein and oil [13]. Our study showed consistent higher concentrations of K, N, P, and B in Gly and K + Gly treatments.

Application of Gly and K + Gly decreased micronutrients $\mathrm{Fe}$ and $\mathrm{Zn}$ concentrations in leaf and seeds of DK 4968 , which is supported by previous research $[12,19$, 20]. However, $\mathrm{Zn}$ increased in cultivar Pioneer 57Y90, suggesting complex genotype $\times$ environment interaction. It was confirmed that Gly application significantly decreased $\mathrm{Fe}$ in plant tissues of glyphosate-resistant soybean. Earlier studies on glyphosate-sensitive sunflower showed that the application of Gly influenced uptake and translocation of micronutrients, including $\mathrm{Fe}, \mathrm{Mn}$, and $\mathrm{Zn}$. It was explained that the reduction of Fe uptake may be due to Fe-Gly complexes. Working on target and nontarget plants and sunflower, other researchers [21] showed that Gly in the rhizosphere can inhibit acquisition of micronutrients that are associated with plant disease resistant mechanism. Iron deficiency has been increasingly observed in crops with frequent Gly applications, and Gly application negatively influenced plant growth and micronutrient levels in plants, even in glyphosate-resistant soybeans [20].

\subsection{Seed Protein, Oil, and Fatty Acids}

Foliar application of $\mathrm{K}$ and Gly treatments resulted in higher protein percentages in all treatments in DK 4968, while oil percentage decreased. However, in Pioneer $95 \mathrm{Y} 70$, protein decreased with Gly treatment. The different response of cultivars to $\mathrm{K}$ and Gly treatments could be due to genotype differences. The different protein /oil ratio in the two cultivars may be due to genotype $\mathrm{x}$ environment interactions which are reported to be significant for seed yield, protein, and oil [22]. The inverse relationship between protein and oil $(\mathrm{r}=-0.87)$ was previously reported $[23,24]$.

The higher protein might be due to increased $\mathrm{N}, \mathrm{K}, \mathrm{P}$, and $\mathrm{B}$ concentrations in leaf and seeds. The role of $\mathrm{K}, \mathrm{B}$, and $\mathrm{Zn}$ in protein synthesis and nitrogen metabolism was reported in other species [18]. Conflicting reports exists on whether or not $\mathrm{N}$ acquisition by plants and $\mathrm{N}$ and $\mathrm{C}$ mobilization from vegetative tissue to seed determine seed protein [17], although a close association exists between soil nutrient levels and protein, oil, and unsaturated fatty acids [24]. The increase of protein by Gly treatments, as previously suggested [25], could be due to altered patterns of nitrogen repartitioning at seed fill in these treatments. Since increased N, P, K, and B concentrations were observed in both leaves and seed, higher uptake and translocation of these minerals from leaves to seed may have occurred, influencing seed protein levels.

Higher percentage of palmitic with $\mathrm{K}$ and $\mathrm{K}+$ Gly and higher percentage of stearic acid in K and Gly treatment in Pioneer $95 \mathrm{Y} 70$ was observed, while oleic acid percentage decreased. This observation was in contrast with previous reports $[24,25]$, where an increased percentage of oleic acid and decreased percentage of linoleic acid were observed. These researchers further reported that saturated fatty acids, palmitic, and stearic percentages were relatively constant. The higher stearic acid and lower oleic acid reported in our study could be due to possible effect of these chemicals ( $\mathrm{K}$ and Gly treatments) on the activity of fatty acid desaturases. The relative stability of saturated fatty acids by $\mathrm{K}$ treatment was reported by others $[24,25]$. The increase in linolenic acid in DK 4968 by combined treatment $(\mathrm{K}+$ Gly) is inconsistent with previous research, indicating that saturated and unsaturated fatty acids response to $\mathrm{K}$ and Gly could be due to genotype differences and genotypes $\times$ environment interactions. The inconsistency in the results in the literature emphasizes the need for further research in the area of glyphosate application and mineral nutrition.

\section{ACKNOWLEDGEMENTS}

We would like to thank Ms. Sandra Mosley for technical assistance and lab analysis. This research was funded by USDA/Faculty Student Research grant at MVSU. The US Department of Agriculture (USDA) prohibits discrimination in all its programs and activities on the basis of race, color, national origin, age, disability, and where applicable, sex, marital status, familial status, parental status, religion, sexual orientation, genetic information, political beliefs, reprisal, or because all or part of an individual's income is derived from any public assistance program. (Not all prohibited bases apply to all programs.) Persons with disabilities who require alternative means for communication of program information (Braille, large print, audiotape, etc.) should contact USDA's TARGET Center at (202) 720 - 2600 (voice and TDD). To file a complaint of discrimination, write to USDA, Director, Office of Civil Rights, 1400 Independence Avenue, S.W., Washington, D.C. 20250 9410, or call (800) 795 - 3272 (voice) or (202) 720 - 6382 (TDD). USDA is an equal opportunity provider and employer.5

Note: If product is small and cannot accommodate full version, short 
version of EEO Statement is acceptable: "USDA is an equal opportunity provider and employer".

\section{REFERENCES}

[1] Vyn, T.J., Yin, X., Bruulsema, T.W., Jackson, C.C., Rajcan, I. and Brouder, S.M. (2002) Potassium placement: What's new for soybeans and corn in conservation tillage systems? Journal of Agricultural Food Chemistry, 50, 3501-3506. doi:10.1021/jf0200671

[2] Chang, E.T., Lee, V.S., Canchola, A.J., Clarke, C.A., Purdie, D.M., Reynolds, P., Anton-Culver, H., Bernstein, L., Deapen, D., Peel, D., Pinder, R., Ross, R.K., Stram, D.O., West, D.W., Wright, W., Ziogas, A. and Horn-Ross, P.L. (2007) Diet and risk of ovarian cancer in the California teachers study cohort. American Journal of Epidemiology, 165, 801-813. doi:10.1093/aje/kwk065

[3] Hasler, C.M. (1998) Scientific status summary on functional foods: Their role in disease prevention and Health promotion. Food Technology, 52, 57-62.

[4] Messina, M. (1995) Modern applications for ancient bean: Soybeans and the prevention and treatment of chronic disease. Journal of Nutrition, 125, 567S-569S.

[5] Messina, M., Gardner, C. and Barnes, S. (2002) Gaining insight into the health effects of soy but a long way still to go: Commentary on the 4th International Symposium on the Role of Soy in Preventing and Treating Chronic Disease. Journal of Nutrition, 132, 547S-551S.

[6] Caragay, A.B. (1992) Cancer-preventive foods and ingredients. Food Technology, 4, 65-68.

[7] Fair, D.E., Ogborn, M.R., Weiler, H.A., Bankovic-Calic, N., Nitschmann, E.P., Fitzpatrick-Wong, S.C. and Aukema, H.M. (2004) Dietary soy protein attenuates renal disease progression after 1 and 3 weeks in Han: SPRD-cy weanling rats. The American Society for Nutritional Sciences, 134, 1504-1507.

[8] Dev, G. (1995) Potassium: An essential nutrient. Use of Potassium in Punjab Agriculture. Potash and Phosphate Institute of Canada, India Programe, Gurgaon, 113.

[9] Myers, S.W., Gratton, C., Wolkowski, R.P., Hogg, D.B. and Wedberg, J.L. (2005) Effect of soil potassium availability on soybean aphid (Hemiptera: Aphididae) population dynamics and soybean yield. Journal of Economic Entomology, 98, 113-120.

doi:10.1603/0022-0493-98.1.113

[10] Hoeft, R.G., Nafziger, E.D., Johnson, R.R. and Aldrich, R. (2000). Modern corn and soybean production. MCSP Publications, Savoy, 353.

[11] Tiwari, S.P., Joshi, O.P. and Billore, S.D. (2001) Realisable yield potential of soybean varieties at farm level in India. In: Souvenier, "Harnessing the Soy Potential of Soybean for Health and Wealth" India Soy Forum SOPA, India, 108-112.

[12] Tiwari, S.P., Joshi, O.P., Vyas, A.K. and Billore, S.D. (2001) Potassium nutrition in yield and quality. 307-320. www.ipipotash.org
[13] Sale, P.W.G. and Campell, L.C. (1986) Yield and composition of soybean seed as a function of potassium supply. Plant and Soil, 96, 317-325. doi:10.1007/BF02375136

[14] Annadurai, K., Seshadri, P. and Palaniappan, S. (1994) Influence of Potassium levels on yield and oil content in sunflower-soybean sequence. Journal of Potassium Research, 10, 124-129.

[15] Bellaloui, N., Reddy, K.N., Zablotowicz, R.M. and Mengistu, A. (2006) Simulated glyphosate drift influences nitrite assimilation and nitrogen fixation in glyphosate-resistant soybean. Journal of Agricultural and Food Chemistry, 54, 3357-3364. doi:10.1021/jf0531981

[16] Anuradha, K. and Sharma, P.S. (1995) Effect of moisture stress and applied potassium on yield and biochemical parameters of soybean in vertisols. Journal of Oilseeds Research, 12, 275-278.

[17] Burton, J.W. (1985) Breeding soybean for improved protein quantity and quality. In: Shibles, R. Ed., World Soybean Research Conference III: Proceedings, Westview Press, Co., Boulder, 361-367

[18] Ruiz, J.M. and Romero, L. (2002) Relationship between potassium fertilization and nitrate assimilation in leaves and fruits of cucumber (Cucumis sativus) plants. Annals of Applied Biology, 140, 241-245. doi:10.1111/j.1744-7348.2002.tb00177.x

[19] Panthee, D.R., Pantalone, V.R., Sams, C.E., Saxton, A.M., West, D.R. and Rayford, W.E. (2004) Genomic regions governing soybean seed nitrogen accumulation. Journal of the American Oil Chemists' Society, 81, 77-81. doi:10.1007/s11746-004-0860-4

[20] Bott, S., Tesfamariam, T., Candan, H., Cakmak, I., Romheld, V. and Neumann, G. (2008) Glyphosate induced impairment of plant growth and micronutrient status in glyphosate-resistant soybean (Glycine max L.) Plant Soil, 312, 185-194. doi:10.1007/s11104-008-9760-8

[21] Neumann, G., Kohls, S., Landsberg, E., Souza, S.K.O., Yamada, T. and Romheld, V. (2006) Relevance of glyphosate transfer to nontarget plants via the rizhosphere. Journal of Plant Diseases and Protection, 20, 963-969.

[22] Wilcox, J.R. and Shibles, R.M. (2001) Interrelationships among seed quality attributes in soybean. Crop Science, 41, 11-14. doi:10.2135/cropsci2001.41111x

[23] Dornbos, D.L. and Mullen, R.E. (1992) Soybean seed protein and oil contents and fatty-acid composition adjustments by drought and temperature. Journal of the American Oil Chemists' Society, 69, 228-231. doi:10.1007/BF02635891

[24] Bellaloui, N., Hanks J.E., Fisher, D.K. and Mengistu, A. (2009) Soybean seed composition is influenced by within-field variability in soil nutrients. Crop management, 56, 2765-2772. doi:10.1021/jf703615m

[25] Bellaloui, N., Zablotowicz, R.M., Reddy, K.N. and Abel, C.A. (2008) Nitrogen metabolism and seed composition as influenced by glyphosate application in Glyphosate resistant soybean. Journal of Agriculture and Food Chemistry, 56, 2765-2772. 